\title{
Introduction: Political Rhetoric in Early China
}

Rhétorique et politique en Chine ancienne

Paul van Els and Elisa Sabattini

\section{(2) OpenEdition}

\section{Journals}

\section{Electronic version}

URL: http://journals.openedition.org/extremeorient/247

DOI: 10.4000/extremeorient.247

ISSN: 2108-7105

\section{Publisher}

Presses universitaires de Vincennes

\section{Printed version}

Date of publication: 1 November 2012

Number of pages: 5-14

ISBN: 978-2-84292-352-5

ISSN: 0754-5010

\section{Electronic reference}

Paul van Els and Elisa Sabattini, «Introduction: Political Rhetoric in Early China », Extrême-Orient Extrême-Occident [Online], 34 | 2012, Online since 01 November 2015, connection on 21 September 2020. URL : http://journals.openedition.org/extremeorient/247 ; DOI : https://doi.org/10.4000/ extremeorient. 247 


\title{
Introduction: Political Rhetoric in Early China
}

\author{
Paul van Els \& Elisa Sabattini
}

\section{Introduction}

Early Chinese thought enjoys a wide appeal, in the scholarly world as much as elsewhere, as people are keen on learning about the ideas of Confucius, Mencius, and other thinkers whose views have shaped traditional Chinese culture. In the study of early Chinese thought, emphasis has long been on what thinkers said, not on how they proffered their views. Even studies that do consider the how, tend to focus on logic and argumentation, rather than rhetoric. Fortunately, in the past few decades growing attention has been paid to Chinese rhetoric which has led to an impressive number of publications. This issue of ExtrêmeOrient, Extrême-Occident feeds into the current debate on Chinese rhetoric by exploring facets that have hitherto been underemphasized, if explored at all. In this introduction, brief outlines of rhetoric in the West and in China are followed by synopses of the six articles in this issue.

\section{Rhetoric in the West}

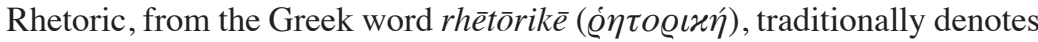
the civic art of speaking in law courts and other formal and political occasions, especially in the democracies of Syracuse and Athens. Rhetoric is often said to have been "invented" in the city-state of Syracuse in the fifth century BCE. After the expulsion in 467 BCE of two tyrant kings, Gelon and Hieron I, citizens were instructed in the art of speech in order to reclaim property seized during the heyday of the two tyrants. ${ }^{1}$ This is when, allegedly, the first rhetorical handbooks

1. Kennedy 1963: 58ff. See also Schiappa 1999. 
were composed.$^{2}$ The democracy of Athens inherited the Syracusian teaching of rhetoric. In Athens, citizens were part of the penal courts. Those who took it upon themselves to accuse or defend a suspect, delivered a public speech in order to convince the jury, which was also made up of citizens. An extensive technical vocabulary and refined techniques were required in order to polish one's argument, arrangement, style, and delivery for persuading the jury. In Syracuse and Athens, the first attempts were made to describe features of a persuasive speech and to teach people how to plan and deliver one. From then on, the study of rhetoric gradually became a regular part of the formal education of young men, and it pervaded not only debate in law courts, where it was born, but also in other activities, such as the literary production of poetry and prose.

At the risk of oversimplifying, three kinds of rhetoric can be discerned in the West, at least according to Chaïm Perelman: ancient rhetoric, classical rhetoric, and new rhetoric. ${ }^{3}$

Ancient rhetoric refers to rhetorical theories developed and practiced in ancient Greece and the Roman world. Important representatives include Aristotle (384-322 BCE), Cicero (106-143 BCE), and Quintilianus (ca 35-100 CE). Aristotle, the great theoretician of rhetoric, famously identified three kinds of persuasive speech (political, legal, ceremonial) and three ways in which persuasion is accomplished (ethos, pathos, $\log o s$ ). Cicero, the great practitioner of rhetoric, emphasized the importance of various forms of appeal in oratory, and stressed that orators must be knowledgeable not just about specific cases of argumentation, but about all areas of human life and culture. Quintilianus, the great teacher of rhetoric, formalized rhetorical training.

Classical rhetoric, as understood by Perelman, started in the sixteenth century with Pierre de La Ramée (1515-1572), who rejected many aspects of ancient rhetorical argumentation, except for elocution (the study of the ornate style). His friend Omer Talon ( $c$ a 1510-1562) was responsible for the first book dedicated exclusively to rhetorical figures (ornate style). Perelman associates the death of ancient rhetoric and the birth of classical rhetoric with these two men. From the mid-sixteenth century to the mid-twentieth century, rhetoric was mostly confined to the study of stylistic devices, such as metaphors. This identification of rhetoric with style is often considered a limitation of the discipline of rhetoric as understood and taught in antiquity, where rhetoric was thought to cover much

2. According to Cicero (Brutus: 46-48), Aristotle identifies the "inventors" of rhetoric as two logographers (speechwriters) named Corax and Tisias, who taught citizens the art of speech in order to reclaim expropriated property, and later composed the first rhetorical handbooks.

3. Perelman 1977: 18-25. 
more than just style. Classical rhetoric is hence seen by Perelman as a pale shadow of ancient rhetoric, and Kennedy likewise defines it as "secondary" rhetoric. ${ }^{4}$

New rhetoric gradually came about through the works of Burke, Perelman, and others, from the 1950s and particularly the 1970s onwards..$^{5}$ It goes back to ancient rhetoric, but its audience has grown. Whereas ancient rhetoric was devised to persuade a group of people in the presence of the speaker, in new rhetoric the audience can range from one person (an internal monologue) to mankind at large. In addition, new rhetoric does not limit persuasion to speech or writing, but also considers other forms of communication. The general idea is that there is no such thing as a non-rhetorical discourse. Rather, rhetoric is that quality in discourse by which agents (speakers, writers, and so on) seek to persuade (or convince, seduce, mesmerize, and so on) their audience. Hence, using Kennedy's words, in "speaking, writing, hearing, and reading, we are better off if we understand the process" of rhetoric. ${ }^{6}$

\section{Rhetoric in China}

Traditionally, the study of rhetoric in the West did not concern itself with non-Western forms of rhetoric. Scholars who did look beyond the geographical boundaries of their field faced severe obstacles, such as the language barrier, as they relied on available translations. Their studies are naturally hampered by the limited number of translated texts, where the quality of the translation may have left something to be desired. ${ }^{7}$ Fortunately, the situation has gradually improved in the last century, particularly during the last few decades.

For Chinese rhetoric, pioneering studies include Crump and Dreher's short papers "Peripatetic Rhetors of the Warring Kingdoms" and "Pre-Han Persuasion" from the early 1950s. These have been followed by a steady flow of books and articles from the 1960s all the way to the present day. Underlying most of these publications appears to be a desire to explore other forms of rhetoric, or to counterbalance the perceived Western monopoly of rhetoric. In recent years a more pragmatic motivation for studying Chinese rhetoric has arisen, as teachers in the West are increasingly exposed to students from different rhetorical traditions. This led to a special issue of the journal College English

4. Kennedy 1984: 3.

5. Burke 1950 and 1967; Perelman and Olbrechts-Tyteca 1969.

6. Kennedy 1994: 10.

7. Lu \& Frank 1993: 447-449, discuss problems due to a dependency on translation in the study of Chinese rhetoric. 
(March 2010) and to Kirkpatrick and Xu's book Chinese Rhetoric and Writing: An Introduction for Language Teachers (2012).

Questions pervading publications on Chinese rhetoric include: What is Chinese rhetoric? Where do we find it? How does it correspond to, or differ from, rhetoric in the West? Answers to these questions vary, depending on the chosen approach. Let us look at a few influential approaches.

One way to study Chinese rhetoric is to select Greek rhetorical figures and show examples of their use in Chinese literature, as Unger does in his Rhetorik des klassischen Chinesisch. Offering Chinese examples for a plethora of Greek rhetorical figures - such as anaphora, ellipsis, and chiasmus-Unger shows that Chinese writers were perfectly capable of using such figures. Still, despite its obvious merits, Unger's approach is not without problems. For instance, a Greek rhetorical figure may be successfully identified in a Chinese text, but that still does not mean it was "applied consistently and deliberately" by Chinese writers. ${ }^{8}$ Moreover, in some cases it takes a rather liberal translation or subjective interpretation of a Chinese passage to make it correspond to a Greek rhetorical figure. For example, Unger uses the saying "the grace of a woman is boundless, the rancor of a wife knows no end" to show that synonyms were used to avoid repetition of words. ${ }^{9}$ However, the words "woman" (nü) and "wife" ( fu) in this saying are not used merely for variation, but as references to different types of females (unmarried $v s$ married). ${ }^{10}$ This leads to a more fundamental problem of the approach, namely that it analyzes the Chinese situation through the lens of Greek rhetoric, which inevitably involves some amount of fitting square blocks into round holes. Through the Greek prism, with its well-defined understanding of rhetoric, any non-Western type likely falls short, much in the same way that the ancient Greeks and Romans may not pass if Chinese forms of rhetoric were to be used as a yard stick. ${ }^{11}$

In full recognition of these difficulties, several scholars, including Oliver and Garrett, emphasize the importance of examining the Chinese rhetorical tradition in its own terms. ${ }^{12}$ Taking this advice to heart, a number of studies have appeared focusing on technical vocabulary used in early Chinese disputation, such as bian

8. Harbsmeier 1999: 121.

9. Unger 1994: 25. He identifies this variation of words as "metaphrase" $\mu \varepsilon \tau \alpha ́ \phi \varrho \alpha \sigma \iota \varsigma$.

10. This was noted by Harbsmeier 1999: 122.

11. This problem also occurs more generally in the study of philosophy, where non-Western philosophies are analyzed from the viewpoint of traditions that developed in the West. See Defoort 2001 on the question whether or not there exists something like a Chinese philosophy.

12. Oliver 1971: 261; Garrett 1993. 
"dispute, debate," shui "discuss, persuade," and shuo "argue, explain." 13 The studies show that Chinese contemporaries of the ancient Greeks not only used rhetorical strategies, but discussed them at a meta-level with a highly developed technical vocabulary. Regrettably, while these meta-discussions throve in the Warring States period, they seem to have ceased as soon as the First Emperor unified these states under the Qin dynasty, which will be grist to the mill of those who maintain that China's rhetorical tradition pales in comparison to that of the West.

The practice of disputation in China may have been relatively short-lived, but China does have a tradition of writing that goes back several thousand years. Most if not all written texts, such as contemplations by thinkers or petitions by ministers, are aimed at persuading the reader and hence involve rhetoric. Not surprisingly, China has a long tradition of reflections, remarks, and comments on rhetoric in writing. A famous early example is The Literary Mind and the Carving of Dragons (Wenxin diaolong) by Liu Xie (ca 467-522) which, among others, recognizes "metaphor" (bi) and "allegory" (xing) in other texts. ${ }^{14}$ Incidentally his book also contains several mentions of "ornate use of words" (xiuci), the term that now translates "rhetoric" in China. Rules of Writing (Wenze) by Chen Kui (1128-1203) examines rhetorical devices used in various early Chinese texts, and is generally considered to be the first systematic account of Chinese rhetoric. ${ }^{15}$ Chen's work was followed by many other books on the topic, such as A Guide to Composition (Wenzhang zhinan) edited by Gui Youguang (15061571). ${ }^{16}$ This tradition fully matured in the early twentieth century, when rhetoric in China became a recognized branch of learning. Chinese scholars started studying Western works of rhetoric and compiling inventories of rhetoric Chinese style. This led to hundreds of monographs, such as Zheng Dian and Tan Quanji's A Compendium of Reference Materials for Ancient Chinese Rhetoric (Gu Hanyu xiucixue ziliao huibian); to monthly academic journals, such as Studying Rhetoric (Xiuci xuexi); to academic centers for the study of rhetoric, for instance at Fudan University in Shanghai; and to a national association and several regional and provincial organizations for the discipline. ${ }^{17}$ Scholars such as Liu Yameng elaborate on this long history of rhetorical reflections to show that it is easily as rich and diverse as that of the West. ${ }^{18}$ One problem with this approach is that all the sources under discussion (e.g. The Rules of Writing,

13. Garrett 1993, Kirkpatrick 1995, Lu 1998.

14. For a study of the rhetoric in this book, see Cai 2001.

15. Kirkpatrick 2005.

16. For a discussion of relevant books on rhetoric in China, see Liu 1996.

17. Kao 1993: 143.

18. Liu 1996. 
A Guide to Composition) deal with writing. This is at odds with Western rhetoric which since its inception has focused on the spoken word. This has led to a view that Chinese narrowly limit rhetoric to stylistic devices in writing, perhaps not unlike de La Ramée, Talon, and other proponents of "secondary" rhetoric in the West. An interesting study by Wu Hui shows how Chinese students in the late nineteenth and early twentieth centuries first encountered Western rhetoric when they studied in Japan, where terms such as xiuci ("ornate use of words") were used to translate rhetoric. ${ }^{19}$ Given that xiuci is traditionally associated with the written word, it is no wonder that Chinese scholars in the past century came to develop an understanding of rhetoric that differs markedly from that in the Western world.

\section{Rhetoric in Early China}

Our goals in this issue of Extrême-Orient, Extrême-Occident are modest. We are not striving to find counterparts for Greek rhetorical figures in China, nor do we expect to lay bare a rich Chinese tradition of theorizing about rhetoric. Instead, we take rhetoric in its broad definition as a tool to inform, persuade, or motivate particular audiences, as we examine how this tool is discussed and employed in early Chinese texts. Through close reading of textual passages from the Warring States period to the Former Han dynasty (roughly the first five centuries BCE) we explore methods or means of persuasion, such as "alienating rhetoric," "rhetoric of treason," or the rhetorical use of anecdotes - forms of rhetoric that are not necessarily congruous with Western rhetorical figures. In this way we hope to show how the masters of early China found unique ways of winning others to their views.

The first two papers analyze the difficulties and dangers of political persuasion in early China. While influential thinkers such as Confucius tried to subjugate discourse to an ethical code and to certify a strict and appropriate relationship between words and deeds, they could not prevent the increasing intellectual and political influence of a new class of orators who, stripped of any moral attachment, consider persuasion from a purely strategic perspective. In the first paper, Albert Galvany shows the essential dynamics of the rhetorical techniques they use, as well as some of the most relevant attempts to neutralize and evade the persuasive capacity of orators, diplomats and counsellors. The latter indicates that game of political persuasion in early China was highly risky and often deadly. This is the topic of the next paper, by Romain Graziani, who identifies and evaluates contrasting attitudes among persuaders, ranging from

19. Wu 2009. 
cognitive optimism to moral pessimism, regarding the capacity of language to convince and influence the listener or improve his moral behavior.

The next two articles deal with overt and covert rhetoric aimed at specific rulers and the ruling elites at large. One of the most overt (and absurd) forms of rhetoric in early China can be found in The Book of Lord Shang (Shangjunshu) by Shang Yang (d. 338 BCE) and his disciples. That book at times adopts a radically alienating rhetoric, attacking ideas and values that were overwhelmingly respected by members of the educated elite. Several chapters deride fundamental moral norms, such as benevolence, righteousness, filiality, fraternal duty, trustworthiness, and honesty; they call for establishing a regime in which "scoundrels rule the good"; and they advocate military victory by performing "whatever the enemy is ashamed of." In the third paper, Yuri Pines argues that the peculiar rhetoric and abusive language might have been designed so as to strengthen Shang Yang's image as a daring and innovative thinker. An apposite example of covert rhetoric can be found in Records of the Historian (Shiji). In some passages of that book, the historian discusses aspects related to the rule of a sage. All aspects he mentions are related to measures taken by the contemporary ruler, Emperor Wu of the Han dynasty (r. 141-87 BCE), thus implying that this emperor could scarcely be regarded as a sage ruler. Moreover, in these passages he even addresses later sages as his expected readers. This address to later sages has a parallel in an earlier text, The Gongyang Commentary (Gongyang zhuan), in a context that can be characterized as "inevitable treason." By alluding to such "treasonous" rhetoric, Schaab-Hanke argues in the fourth paper, the author of Records of the Historian incurred the risk of being charged with high treason.

The last two articles describe the use of historical anecdotes and political slogans as rhetorical tools. Early Chinese argumentative texts are full of historical anecdotes. These short accounts of events in Chinese history enhance the appeal of the text, but they also have an important rhetorical function in helping the reader understand, accept, and remember the arguments propounded in the text. The fifth paper examines the rhetorical function of historical anecdotes in two argumentative texts of the Western Han dynasty (202 BCE-9 CE): Han's Illustrations of the Odes for Outsiders (Han shi waizhuan) and The Master of Huainan (Huainanzi). These two texts found creative use for anecdotes, namely as illustrations of quotations from canonical sources. Through case studies of several combinations of anecdotes and quotations, the paper argues that the combinations serve to present the creators of these texts as beacons of knowledge with profound understanding of historical events and canonical literature, and with the necessary skills to fruitfully combine the two. The final paper focuses on the rhetorical expression "people as root" (min ben) in New Writings (Xin 
shu) ascribed to Jia Yi, a young prodigy active at the court of Emperor Wen (r. 179-157 BCE). The paper shows that in New Writings the appeal to the people is due to its emotive connotation rather than signifying a concrete set of people-oriented policies. Here the term "people" becomes an instrument used to reassess the young Han imperial interests. The expression "people as root" is thus part of the strategy of Jia Yi's political persuasion.

\section{BibliogRAPHY}

BISCHOFF, Friedrich Alexander (1976). Interpreting the fu: A Study in Chinese Literary Rhetoric. Wiesbaden, Franz Steiner Verlag.

Burke, Kenneth (1950). A Rhetoric of Motives. New York, Prentice-Hall.

Burke, Kenneth (1951). "Rhetoric-Old and New." The Journal of General Education, no. 5.3: 202-209.

CAI, Zong-Qi (ed.) (2001). A Chinese Literary Mind: Culture, Creativity, and Rhetoric in Wenxin diaolong. Stanford, Stanford University Press.

Crump, James (1964). Intrigues of the Warring States: Studies of the Chan-kuo Ts'e. Ann Arbor, University of Michigan Press.

Crump, James (1998). Legends of the Warring States: Persuasions, Romances, and Stories from Chan-kuo Ts'e. Ann Arbor, The University of Michigan Center for Chinese Studies.

CRUmp, James and DreHER, John (1951). "Peripatetic Rhetors of the Warring Kingdoms." Central States Speech Journal, no. 2: 15-17.

Dance, Frank (1981). "The Tao of Speech.” Central States Speech Journal, no. 32: 207-211.

Defoort, Carine (2000). "Review of Xing Lu's Rhetoric in Ancient China, Fifth to Third Century BCE-A Comparison with Greek Rhetoric (Columbia, SC: University of South Carolina Press, 1998)." The Journal of Asian Studies, no. 59.3: 709-710.

Defoort, Carine (2001). "Is there such a thing as Chinese philosophy? Arguments of an implicit debate." Philosophy East and West, no. 51.3: 393-413.

DreHER, John and CRUMP, James (1952). "Pre-Han persuasion: the Legalist School." Central States Speech Journal, no. 3: 10-14.

Garrett, Mary (1993). "Classical Chinese Rhetorical Conceptions of Argumentation and Persuasion." Argumentation \& Advocacy, no. 29.3: 105-115.

Garrett, Mary (1993). "Pathos reconsidered from the Perspective of Classical Chinese Rhetorical Theories." Quarterly Journal of Speech, no. 79: 13-39.

Harbsmeier, Christopher (1999). “Chinese Rhetoric.," T'oung Pao, no. 85: 114-126.

JENSEN, Vernon (1987). "Rhetoric of East Asia: A Bibliography." Rhetoric Society Quarterly, no. 17: 213-231.

JENSEN, Vernon (1987). "Rhetorical Emphases of Taoism.” Rhetorica, no. 5.3: 219-229. JENSEN, Vernon (1992). "Values and Practices in Asian Argumentation." Argumentation and Advocacy, no. 28: 155-166. 
KAO, Karl (1986). "Rhetoric.” In Nienhauser, William H. (ed.), The Indiana Companion to Traditional Chinese Literature, Volume 1. Bloomington, Indiana University Press: 121-137.

KAO, Karl (1993). "Recent Studies of Chinese Rhetoric.” Chinese Literature: Essays, Articles, Reviews, no. 15: 143-154.

Kennedy, George (1957). “The Ancient Dispute over Rhetoric in Homer.” The American Journal of Philosphy, no. 78.1: 23-35.

Kennedy, George (1963). The Art of Persuasion in Greece. Princeton, Princeton University Press.

Kennedy, George (1984). New Testament Interpretation through Rhetorical Criticism. Chapel Hill, N.C., The University of North Carolina Press.

Kennedy, George (1994). A New History of Classical Rhetoric. Princeton, Princeton University Press.

Kennedy, George (1999). Classical Rhetoric and its Christian and Secular Tradition from Ancient to Modern Times. Chapel Hill, N.C., The University of North Carolina Press.

KIRKPATRICK, Andy (1995). "Chinese Rhetoric-Methods of Argument." Multilingua, no. 14.3: 271-295.

KirKPatrick, Andy (2005). "China's First Systematic Account of Rhetoric: An Introduction to Chen Kui's Wen ze." Rhetorica, no. 23: 103-152.

KIRKPATRICK, Andy and Xu, Zhichang (2012). Chinese Rhetoric and Writing: An Introduction for Language Teachers. Fort Collins, The WAC Clearinghouse.

Liu, Yameng (1996). "To Capture the Essence of Chinese Rhetoric: An Anatomy of a Paradigm in Comparative Rhetoric." Rhetoric Review, no. 14.2: 318-335.

Lu, Xing (1998). Rhetoric in Ancient China, Fifth to Third Century BCE. Columbia, University of South Carolina Press.

Lu, Xing (2002). "Comparative Studies of Chinese and Western Rhetorics: Reflections and Challenges." In Wenshen Jia, Xing Lu, and D. Ray Heisey (eds), Chinese Communication Theory and Research. Westport, Ablex: 105-120.

Lu, Xing and Frank, David (1993). "On the Study of Ancient Chinese Rhetoric/Bian 辯.” Western Journal of Communication, no. 57: 445-463.

MAo, LuMing (2007). "Studying the Chinese Rhetorical Tradition in the Present: Representing the Native's Point of View." College English, no. 69.3: 216-237.

MAO, LuMing (2010). "Searching for the Way: Between the Whats and Wheres of Chinese Rhetoric.” College English, no. 72.4: 329-349.

OlIVER, Robert (1961). "The Rhetorical Implications of Taoism.” Quarterly Journal of Speech, no. 47: 27-35.

Oliver, Robert (1969). "The Rhetorical Tradition in China: Confucius and Mencius." Communication Quarterly, no. 17: 3-8.

Oliver, Robert (1971). Communication and Culture in Ancient India and China. Syracuse, Syracuse University Press.

Perelman, Chaïm (1977). L'Empire rhétorique. Rhétorique et argumentation. Paris, Librairie hilosophique J. Vrin. 
Perelman, Chaïm and Olbrechts-Tyteca, Lucie (1969). The New Rhetoric. A Treatise on Argumentation. Notre Dame, University of Notre Dame.

REYNOLDS, Beatrice (1969). "Lao Tzu: Persuasion Through Inaction and Non-speaking." Communication Quarterly, no. 17: 23-25.

SAnFt, Charles (2002). "Review of Xing Lu's Rhetoric in Ancient China, Fifth to Third Century BCE-A Comparison with Greek Rhetoric (Columbia, SC, University of South Carolina Press, 1998)." Quarterly Journal of Speech, no. 2002.2: 144-146.

Schiappa, Edward (1999). The Beginning of Rhetorical Theory in Classical Greece. New Haven, Yale University Press.

UnGER, Ulrich (1994). Rhetorik des klassischen Chinesisch. Wiesbaden, Harrassowitz Verlag.

Wu, Hui (2009). "Lost and Found in Transnation: Modern Conceptualization of Chinese Rhetoric." Rhetoric Review, no. 28.2: 148-166.

Xu, George (2004). “The Use of Eloquence: The Confucian Perspective.” In Lipson, Carol and Binkley, Roberta (eds), Rhetoric Before and Beyond the Greeks. Albany, State University of New York Press: 115-130.

\section{Glossary}

bi 比

bian 讋

Chen Kui 陳騤

fu 婦

Gongyang zhuan 公羊傳

Gui Youguang 歸有光

Han Feizi 韓非子

Han shi waizhuan 韓詩外傳

Huainanzi 淮南子

Jia Yi 賈誼

Liu Xie 劉劦思

min ben 民本

nü 女

Shiji 史記

shui 說

shuo 說

Wenxin diaolong 文心雕龍

Wenze 文則

Wenzhang zhinan 文章指南

xing 興

$X i n s h u$ 新書

xiuci 修辭

xuexi 學習

Zhanguoce 戰國策

Zhuangzi 莊子 